\title{
Appointment of Politically Connected Top Executives and Subsequent Firm Performance and Corporate Governance: Evidence from China's Listed SOEs*
}

\author{
Fang Hu \\ Department of Accounting, Finance and Economics \\ Griffith Business School, Griffith University \\ Email: f.hu@griffith.edu.au \\ Fax: +61 737353719 \\ Sidney C. M. Leung \\ Department of Accountancy, Faculty of Business, \\ City University of Hong Kong. \\ Email: acsleung@cityu.edu.hk \\ Fax: +852 34420349
}

March 2011

\footnotetext{
${ }^{*}$ We appreciate comments from Kevin Lam, Grant Richardson, Bikki Jaggi, Bin Ke, Ji-Chai Lin, Feng Liu, Shiguang Ma, participants of the 2009 Asian Finance Association annual meeting and the International Conference of Economic, Finance and Accounting (IEFA) at Taiwan National University, and seminar participants at the City University of Hong Kong.
} 


\title{
Appointment of Politically Connected Top Executives and Subsequent Firm Performance and Corporate Governance: Evidence from China's Listed SOEs
}

\begin{abstract}
This paper investigates the decision to appoint politically connected top executives to Chinese listed state-owned enterprises (SOEs) when they face distressful conditions and whether such appointments enhance or reduce firm performance and corporate governance in subsequent years. China is the world's largest emerging economy, and Chinese SOEs are under intensive state control and are obliged to draw on a less developed managerial labor market. Using data on the top-management turnover of listed SOEs from 2001 to 2005, we find that state-owned companies are more likely to replace top executives and appoint a politically connected executive when they encounter a distress such as poor ROA, an earnings loss, a high financial risk, or regulations violation. We also find that newly appointed politically connected top executives subsequently improve firm performance and governance structures and reduce the frequency of illegal action by firms. However, there is no evidence that newly appointed politically connected top executives benefit firms through affording them preferential access to resources or government assistance. The findings suggest that politically connected executives may be selected for the alignment of shareholders' interests and for their special managerial talent in emerging markets dominated by government ownership, and may display additional managerial productivity in such an environment.
\end{abstract}

Keywords: Appointment of top executives, politically connected executives, firm performance, corporate governance. 


\section{Introduction}

Decisions on top management appointments and selection and their impact in a developed managerial labor market have been the subject of considerable research (e.g., Agrawal et al., 2001; Cannella et al., 1993; Dalton et al., 1983; Warner et al., 1988; Weisbach, 1988; Pfeffer, 1981; Puffer and Weintrop, 1991). However, the picture is relatively incomplete in less developed markets in which political connections and influence play a significant role in both the micro and macro economic environments.

The Chinese political hierarchy is often viewed as a single internal labor market, and has played a significant role in the course of China's remarkable economic growth (Li et al., 2005). Government officials often take up top management positions in state-owned enterprises (SOEs). This pattern of political leadership recruitment has received widespread attention in the political, sociological, and economic literature. In a sample of firms in which the chairman of the board or CEO was replaced during the period 2001 to 2005, more than one half of the newly appointed top executives who replaced them had a political background (Table 1). In the last decade, the frequency of newly appointed top executives (chairman of the board or CEO) in SOEs who have experience in government or the Communist Party has risen by around 1\%. The highest frequency of the appointment of politically connected executives occurs in the poorest (or least developed) Northwest region. ${ }^{1}$ Some of the newly appointed executives formerly held a top-ranking position in the government such as vice mayor or vice governor of a province. Anecdotal evidence indicates that in some Chinese SOEs, the government appoints a government

\footnotetext{
1 We compare appointment patterns across the 10 years from 1996 to 2005, benchmarked against firm performance or level of distress (not reported). We find that the frequency of the appointment of political executives increases gradually over the 10 years, alongside a gradually increase in the frequency of earnings losses and regulations violations, and in the mean debt-to-assets ratio. We also plot the frequency of the appointment of politically connected executives against mean GDP in various regions (North, Northeast, East, Central, Southwest, and Northwest). The figures (not reported) show that the frequency of the appointment of politically connected executives is inversely related to the wealth of the area. The poorest area, the Northwest, has the highest frequency of the appointment of politically connected executives, and the richest area, the East, has the lowest frequency.
} 
official to replace the chairman of the board or chief executive officer (CEO) in government-affiliated enterprises when these enterprises encounter financial performance difficulties. For example, in 2004, the local government appointed Mr. Zhao Yong, who was vice mayor of Mianyang in Sichuan Province, to the position of chairman of the board in a local "backbone” state enterprise, Sichuan Changhong Electric Co. (SEC code: 600839), which had suffered huge losses following fraud and legal disputes with APEX Co. in the United States (more examples are given in Appendix C). ${ }^{2}$

Leadership recruitment and its impact on firm performance and corporate governance in an emerging market are controversial issues. Emerging economies rely more on personal relations (guanxi in China) to govern firms, and several recent studies have reported evidence that managerial talent or effort may be less important in emerging economies than in developed economies (Adhikari et al., 2006; Li et al. 2003; Rajan and Zingales, 1998, 2003; Peng and Luo, 2000; Francis, et al., 2009). According to this managerial productivity hypothesis, the professionalism of political leaders in business is doubtful, and having politically connected top executives may be detrimental to firm efficacy (Chen et al., 2002; Fan et al., 2007). However, others argue that the value embedded in political ties may be important in emerging markets characterized by weak institutional support and distorted information (Peng and Luo, 2000; Li et al., 2003; Francis et al., 2009), and posit that executives with political ties may have a stronger incentive or more ability to achieve better managerial productivity in such an environment. It is argued that the strong pro-business incentives of Chinese officials stand in stark contrast to the rent-seeking behavior of government officials in other transitional and developing countries because of their political incentives or career prospects in the bureaucracy, which generates an alignment of political and corporate interests ( $\mathrm{Li}$ and Zhou, 2005). Due to the dominance of

\footnotetext{
${ }^{2}$ The source is news in Chinese on the Internet.
} 
government ownership and the substantial government involvement in the economy, the ability of a top manager to effectively deal with public commissions and to successfully navigate the governmental process is likely to be important (Hadlock et al., 2002). Given the controversy surrounding the appointment of top managers with a political background to business enterprises, it is worthwhile to investigate the appointment of politically connected top executives and its consequences for firm performance and corporate governance. Addressing these issues will help us to better understand the roles of politicians in business and the nature of corporate governance mixed with government control.

We use 696 listed SOEs in China from 2001 to 2005 as the sample. The empirical results show that SOEs are more likely to replace the incumbent chairman or CEO and to appoint a politically connected executive when they display poor performance or distress, which suggests that political executives are perceived to play a helping role. The results of a logistic regression show that the appointment of politically connected executives is significantly positively associated with poor performance (economic distress), such as poor accounting performance (ROA), an earnings loss (a net income of less than 0), or a high degree of financial risk, or political distress, such as the violation of SEC regulations. In contrast, the appointment of politically unconnected managers is not significantly associated with firm performance.

The second part of the study evaluates firm performance, corporate governance structure and government assistance subsequent to the appointment of politically connected top executives, in an effort to evaluate whether the appointment of top managers with a political background is beneficial or detrimental to shareholders. Some scholars argue that newly appointed politically connected executives do display greater managerial productivity and do play a monitoring or disciplinary role in corporate governance due to their greater accountability in the internal 
political hierarchy (Li et al., 2005), administrative power (Cannella and Lubatkin, 1993), regulatory expertise (Agrawal and Knoeber, 2001), and regulatory or political oversight (Agrawal et al., 1999), and to the greater political checks and balances to which they are subject (Qian, 1996; Li, 2000; Chang and Wong., 2004). Others believe, however, that new politically connected executives do not display greater managerial productivity, and are only appointed to assure a bailout by the government (Krueger, 1990; Qian and Gerard, 1996; Shirley and Walsh, 2000; Faccio, 2006). This line of research suggests that if firm performance is improved following the appointment of a politically connected executive, then this is due to government assistance, rather than the ability and expertise of the executive. We thus also examine whether government assistance increases following the appointment of political top managers.

Our empirical test of the consequences of appointing politically connected top executives with an event period of two years before to three years after the appointment shows that the accounting firm performance (ROA) of SOEs significantly increases, and that there is a lower frequency of earnings losses and of regulations violations following the appointment of political executives. Such improvements in performance are not observed for firms that appointed top executives with no political background, or non-political executives. In particular, in the three years following the appointment of political executives, the frequency of regulations violations is significantly lower, at around 5\% less, than is the case after the appointment of non-political executives. The results also show that corporate governance indicators such as the percentage of independent directors on the board, the holding of the chairman and CEO positions by the same person, and the number of board meetings held improve to some extent following the appointment of political executives. In the year $t+1$ following the appointment of a political executive, discretionary accruals, which is a proxy for managerial opportunistic behavior, 
decrease significantly to -0.008 . Further, the percentage of independent directors on the board increases significantly in the years following the appointment of political executives, and is no lower than the corresponding percentage following the appointment of non-political executives. In the year $\mathrm{t}+2$ following the appointment of a political executive, the frequency of combining the top two positions is significantly lower, at around $5 \%$ less, than after the appointment of non-political executives, and board meetings are held significantly more frequently after the appointment of political executives. These findings indicate that political executives do initiate changes in and improve corporate governance structures. We also find no significant changes in subsidies from government (scaled by sales), tax rate, interest rate, and long-term loans following the appointment of political executives. The results provide no evidence that politically connected top managers seek more government assistance or preferential access to capital resources.

The findings of this study contribute to the literature in several ways. First, although past studies have indicated the potential importance of the managerial appointment decisions made by shareholders in a competitive managerial labor market (Shleifer and Vishny, 1994; Huson et al., 2004; Denis and Denis, 1995; Bonnier and Bruner, 1989), there is little direct evidence regarding the effects of the managerial labor market and corporate governance in emerging economies in which market-supporting institutions are not fully developed. Second, most existing studies focus on the rent-seeking objectives of government and neglect its shareholding or pro-business incentives (Hellman and Schankerman, 2000; Fan et al., 2007). By studying the appointment of politically connected top managers to SOEs and the consequences for firm performance and corporate governance structures, we provide a better understanding of government interest and 
control in SOEs. ${ }^{3}$ Third, the findings extend past research on the influence of the political ties of managers on firm value and corporate governance. A concern that has arisen in past research, whether it be on the "pros" of political connections, as identified by Faccio et al. (2006) or the "cons" of political connections, as suggested by Fan et al. (2007), is whether or not the political connections that we observe come about because a firm is in need of immediate political connections or capital. That is, the observed association between political connections and their relevant effects may be a "marriage of convenience" in which the connections are established for the specific purpose of seeking benefits. Management turnover cases provide a dynamic setting to control for the problems of ambiguous incorporated institutions or self-selection inherent in past research. Finally, despite the criticism that the Chinese economy lacks a functioning capital market and significant investor protection and is subject to extensive government influence and control, China has experienced remarkably rapid economic growth in the last two decades. Our findings of a positive relation between the appointment of politically connected top managers to SOEs and improvement in firm performance and corporate governance provide a partial explanation for this intriguing phenomenon.

The remainder of this paper proceeds as follows. Section 2 discusses the background to the study. Section 3 develops the hypotheses, and distinguishing the various views on the subject in context. Section 4 presents the research design, and Section 5 describes the data and sample. Section 6 reports the results and the robustness checks, and Section 7 concludes.

\section{Institutional Backgrounds of Chinese SOEs}

\footnotetext{
${ }^{3}$ Past studies (Shleifer and Vishny, 1997; Claessens and Fan, 2002) suggest external market mechanisms such as bankruptcy or the takeover of failing firms. However, these external market controls do not apply to SOEs because of soft-budget constraints in these enterprises (Krueger, 1990; Qian and Gerard, 1996).
} 


\subsection{Managerial labor market and management appointments in Chinese SOEs}

Unlike corporate managers or politicians in Western countries, the Chinese political hierarchy, including government entities, industrial bureaus, and SOEs, can be viewed as a single internal labor market. Competition is lacking because the government still determines the appointment of senior executives in state enterprises. The Central Committee of the Chinese Communist Party (CCP), which functions more or less as the personnel department of this enormous organization, ultimately controls the mobility of government officials within the system, maintaining dossiers and tracking managerial careers. ${ }^{4}$ The lock-in effect, coupled with the huge difference in the personal benefits of staying in power and relinquishing power, greatly reinforces the incentive for Chinese officials to hold onto power. $^{5}$ If an official is separated from the government hierarchy, his or her career in the political system is disrupted ( $\mathrm{Li}$ et al. 2005). Chinese government officials have traditionally had few options outside the internal political labor market. ${ }^{6}$ This highly centralized structure of personnel control remains largely intact today.

In this internal political labor market, the government has mixed incentives in the selection and assignment of managers in SOEs. The main role of government in SOEs is to be the largest shareholder. In addition to social and political goals, state shareholders also have ownership interests in the profitability of their companies (Frydman et al., 1996; Blanchard et al., 2001; Hellman and Schankerman, 2000; Oi, 1992; Qian and Xu, 1993; Maskin et al., 2000; Montinola et al., 1995; Qian and Weingast, 1997). However, the state faces the same agency problem as firms in developed markets due to the separation of ownership and control. Managers are

\footnotetext{
${ }^{4}$ In China, personnel control is centralized in the hands of the Communist Party (CCP) and the government. The State-owned Assets Supervision and Administration Commission (SASAC), which is authorized by the state-level or local-level CCP and government, is responsible for investing in state-owned assets on behalf of the central or local government, and one of its tasks is to select and appoint the management of SOEs (refer to the Web page of the SASAC (www.sasac.gov.cn) for more details).

${ }^{5}$ The chairman of the board of an SOE may be promoted to hold a leading position in local or central government, such as vice mayor, vice province governor, or state secretary.

${ }^{6}$ Since the mid-1990s, China's private sector, which is relatively free from the Party's control, has become a large employer in the labor market, and government officials can now leave the government and seek employment in private companies.
} 
motivated by self-interest, and may thus use the resources of state-owned firms to promote their own personal interests (Shleifer and Vishny 1994, 1998; Jones, 1985; Krueger, 1990). The alignment of incentives is thus critical in the selection of a manager.

The other role of government is political and regulatory. Government officers or bureaucrats seek to serve certain social and political interests, such as correcting market failures and providing additional employment opportunities and social security to the public (Shleifer et al. 1994, 1998). Managers acting on behalf of the government are seen as semi-officials, and are assumed to be involved in regulatory procedures. As a result, appropriate supervision and the replacement of non-complying managers is at best a weighted average of the government's shareholding incentives and non-economic goals.

\subsection{Interest and Control of State Owners in Chinese SOEs}

State owners in Chinese SOEs potentially have multiple objectives. A state owner is usually the largest shareholder in an SOE and faces similar incentive misalignment problems between shareholders and managers as are commonly found in privately owned firms. On the one hand, state owners are interested in maximizing the profitability of their companies (Frydman et al., 1996; Hellman and Schankerman, 2000). On the other hand, state owners also have social and political goals. Government officials and bureaucrats are often appointed as top managers (chairman or CEO) to SOEs to serve social and political interests, such as correcting market failure and providing additional employment opportunities (Shleifer and Vishny, 1994, 1998).

The Chinese central government has emphasized and implemented various policies to boost the economic performance of Chinese SOEs since embarking on its economic reforms in the 
1980s. Performance contracts have commonly been used between managers and state owners to improve firm performance and monitor managers (Shirley and $\mathrm{Xu}$, 2001). The central government has also decentralized certain revenue and expense responsibilities to lower levels of governments, which means that local governments have the power and responsibility to enhance regional economic performance (Oi, 1992; Montinola et al., 1995; Qian and Weingast, 1997). The central government rewards or punishes local government officials on the basis of economic performance in their region, which motivates them to promote the local economy and SOE performance (Blanchard and Shleifer, 2001). The career prospects of government officials and bureaucrats are determined by the economic performance of their region relative to its peers (Qian and Xu, 1993; Maskin et al., 2000). Thus, government officials who are appointed as top managers of SOEs have a strong incentive to enhance firm performance and governance to discharge their responsibilities and stand out in the political competition for career promotion.

\section{Hypothesis Development}

The relationship between managerial appointments and firm performance has been well established in the literature for private, diffuse-owned firms in developed markets, and three general conclusions have been drawn. First, in response to poor performance, shareholders may remove incumbent executives and appoint new executives who are perceived to be likely to help to improve performance for firm survival (Guest, 1962; Helmich and Brown, 1972; Pfeffer, 1981; Dalton and Kesner, 1983; Schwartz and Menon, 1985). Second, in response to good performance, newly appointed executives are perceived to maintain a firm's strategy or act out of self-interest (Morck et al., 1988; Puffer and Weintrop, 1991). Third, the appointment of top executives may have nothing to do with previous firm performance. Rather, the relationship between the 
appointment of executives and previous firm performance reflects the perception of shareholders of the role of certain types of executives in corporate governance.

The literature on emerging economies suggests that governments appoint politically connected executives to SOEs for three main reasons: to extract rents from firms, or the grabbing hand model (Shleifer and Vishny, 1994, 1998; Chang and Wong, 2004; Fan et al., 2007); to control agency problems politically, or the helping hand model (Shleifer and Vishny, 1998; Qian, 2000; Li, 2000; Chang and Wong, 2004); or to serve as window dressing.

Overall, the findings on the relationship between the appointment of politically connected top management and firm performance remain inconclusive for emerging economies such as that of China, where patterns of political leadership recruitment have been the focus of much research attention. The incentives of the government in assigning political leaders in business remain unclear, and whether they are selected and recruited based on the performance hypothesis (Kato and Long, 2006; Opper and Brehm, 2007) has yet to be confirmed. Scholars have also expressed doubts about the professionalism of managers appointed by the government (Chen et al., 2002; Fan et al., 2007). Hence, it is worthwhile to examine the appointment of government officials as top managers in SOEs in response to firm performance, and its subsequent effects on firm performance and governance structures.

\subsection{Appointment of Politically Connected Top Management and Past Firm Performance}

The economics literature holds that management in institutions is endogenously determined to mitigate conflicts of interest between managers and shareholders (Fama and Jensen, 1983). The Chinese economic reform has generated a conflict in the managerial incentive system of SOEs. On the one hand, governments adopt performance-based incentive contracts to align the efforts 
of SOE managers with the economic performance of firms. In these performance contracts, SOE top managers promise to achieve specified earnings targets in a given period, and the government rewards such achievement and punishes failure (Aivazian et al., 2005; Chang and Wong, 2009; Shirley and Xu, 2001). On the other hand, performance-based contracts officially grant SOE managers more decision rights over such matters as production, pricing, investment, the disposal of state assets, the use of retained funds, and internal organization. Managers thus have more opportunity to take bribes or divert state resources for their own private benefit. In emerging markets that lack a competitive managerial labor market and strong legal protection for investors in which managers are under less pressure from the external labor market and face fewer legal risks arising from misconduct, performance-based incentives alone may not be sufficient to monitor managers’ performance, and a misalignment of interests between state owners and top managers may result. In this scenario, state owners may adopt an alternative incentive-alignment system, such as political checks and balances, political conformity, or threatening the career of managers in the internal political hierarchy. Hence, when SOEs face distress or mismanagement, appointing politically connected government officials as top managers effectively ensures that the state's goals and objectives are protected and achieved.

Government officials have an advantage in terms of managerial talent, including administrative power and experience (Cannella and Lubatkin, 1993). China's open door policy and economic development over the last 30 years has provided tremendous opportunities to nurture government officials and bureaucrats and develop their managerial ability. In addition, as government ownership and substantial government involvement are dominant phenomena in the Chinese economy, the ability of a top executive to effectively deal with public commissions and to successfully navigate the governmental process is likely to be important part of managerial 
ability (Hadlock et al., 2002), and politically connected managers are more likely to possess these managerial skills. Cannella and Lubatkin (1993) suggest that the social and political capital of executives gives them more power to deal with current critical contingencies, which enables them to influence internal governance decisions. Agrawal and Knoeber (2001) suggest that politically connected executives have regulatory expertise and experience in government procedures. Agrawal et al. (1999) find that firms discovered to have violated governmental regulations are inclined to hire new senior managers with political and regulatory connections to rebuild their destroyed reputational capital with regulators and to offer advice under increased regulatory or political oversight. This line of argument suggests that appointing politically connected top managers may help SOEs.

Rent seeking may be another reason for appointing politically connected managers. A rent-seeking government is more likely to endorse a bureaucrat's appointment as a manager of a business (Fan et al., 2007). Politically connected managers may collude with the government to extract the earnings of firms to pursue social objectives or private gains at the firm's expense, which is not conducive to the maximization of profitability. The presence of former bureaucrats in business creates an environment in which government and business are not separate, which leads to collusion between government and business and to corruption (Chen et al., 2002).

Given the policy of the Chinese central government to enhance the economic performance of SOEs, the managerial talents of Chinese government officials, and the policy of evaluating government officials for promotion based on regional economic performance, as discussed in Section 2, the following hypothesis is proposed.

Hypothesis 1 (H1): The appointment of politically connected top executives in SOEs is 
positively associated with past poor firm performance or distress.

\subsection{Appointment of Politically Connected Top Management and Post-appointment Firm Performance and Corporate Governance}

As discussed in the foregoing sub-section, the appointment of politically connected top managers in SOEs may be due to the helping-hand interests of government in terms of incentive alignment and the managerial talent of politically connected managers or due to the grabbing-hand interests of government in the form of rent seeking. An examination of the changes in post-appointment firm performance and corporate governance structures should enable us to evaluate the incentives behind appointment decision and the consequences of such decisions for the shareholders of SOEs.

There are various views on ex-post productivity and the consequences of appointing politically connected managers.

Managerial productivity. As elaborated in the previous sub-section, politically connected top managers may be more accountable in the internal political hierarchy and have more managerial skills in an environment in which the government dominates. These include skills to deal with administrative power (Cannella and Lubatkin, 1993), regulatory expertise (Agrawal and Knoeber, 2001), regulatory or political oversight (Agrawal et al., 1999), and political checks and balances (Qian, 1996; Li, 2000; Chang and Wong, 2004). In our sample, we find that almost 80 percent of newly appointed politically connected top managers also have extensive experience in industrial bureaus or businesses. We thus expect politically connected top managers to initiate changes and improvements to business operations and internal corporate governance structures, resulting in better firm performance. We thus offer the following hypotheses. 
Hypothesis 2 (H2): The appointment of politically connected top managers is positively associated with subsequent changes in firm performance.

Hypothesis 3 (H3): The appointment of politically connected top managers is positively associated with subsequent improvment in internal corporate governance.

Government bailout. Some researchers argue that political executives are appointed to SOEs as an insurance for obtaining a government bailout, and do not display managerial productivity (Krueger, 1990; Kornai, 1980). Governments and politicians commit to subsidizing SOEs, and especially loss-making SOEs, by according certain benefits to them, such as protecting local markets by creating trade barriers, giving them exclusive business rights, and injecting financing resources through government-directed banks (Chen et al., 2002; Qian and Gerard, 1996; Shirley and Walsh, 2000).

This leads to the following hypothesis on whether the political capital of politically connected managers increases government assistance to a firm (in alternative form).

Hypothesis $4(\mathrm{H} 4)$ : The appointment of politically connected top managers is positively associated with subsequent changes in government assistance.

\section{Research Design}

\subsection{Measures}

Political background of top managers

Given the dual presence of the CCP and government organs at each level of China's 
political hierarchy (Whiting, 2001), a chairman of the board or CEO is identified as having political expertise or a political background if i) he or she has had experience working in state-level or local-level government entities (including the military); or ii) has held one of three main party positions - Party Secretary, Central Committee Member, or Representative of the National People's Congress. In the sample, the appointment of a politically connected top manager is defined as either a chairman or a CEO who has been newly appointed and has either of the two political backgrounds described.

\section{Poor firm performance (distress)}

We focus on two kinds of distress in measuring firm performance: economic distress and political distress. The data for measuring distress are obtained from CSMAR. The three measures of economic distress are: i) accounting firm performance (ROA) (suggested by EHW, 2003; Chang and Wong, 2004; Kato and Long, 2006) ${ }^{7}$; ii) earnings loss, which is a dummy variable that equals 1 if net income is less than 0 ; and iii) financial distress, as measured by the debt to assets ratio (DA), which is used to determine the leverage risk (suggested by Gilson, 1990, among others). The measure for political distress is a dummy variable for the firm year in which the company violated regulations or laws as disclosed by the SEC (suggested by Sun and Zhang, 2006; Agrawal et al., 1999).

\subsection{Model}

To test the relationship between management appointments and past firm performance, the following LOGIT model is applied.

\footnotetext{
${ }^{7}$ An alternative measure in the literature is firm market performance (stock price). However, Chang and Wong (2006) suggest that managerial change and selection in Chinese SOEs is not significantly associated with stock price performance because state-owned shares are usually non-tradable and can only be transferred following administrative approval. Further, the SASAC or bureaucrats who exercise control on behalf of the government are unable to personally capture any capital gains when enterprise shares are transferred. Consequently, state owners may be less concerned about long-term shareholder value as reflected in stock prices. We also conduct the main test using stock price performance, but find no significant associations in the results.
} 
$\operatorname{Logit}($ Appoint ment $)=\alpha+\beta_{1} *$ Performance $_{i t-1}+\beta_{2} * C V_{i t-1}+\varepsilon_{i t}$,

where

Appointment $=1$ if the newly appointed top executive (chairman or CEO) is politically connected, and 0 otherwise; and

Performance $_{i t-1}=$ the four performance measures described earlier.

The control variables for the lagged one period $\left(C V_{i t-1}\right)$ are as follows.

Log (Assets) controls for firm size. Faccio (2007) argues that larger firms are more likely to be subject to political scrutiny and government control due to their greater importance to the local economy and regional development. Hence, the government is likely to select top executives with political background for large firms.

Log(Employee) controls for the number of employees. Both SOEs and politicians share the social goal of employment. Some researchers argue that managers in state enterprises are also evaluated on the basis of social duties, such as maintaining and increasing employment (Fan et al., 2007). Hence, the government is likely to select top executives with political backgrounds if the unemployment rate is high.

$\log (G D P)$ controls for the economic conditions of the labor market in various regions. This is associated with management turnover because of differences in local labor markets and local economic development (Fan et al., 2007).

Indus_ $M B$ is the industry median market-to-book ratio as determined by two-digit SIC code, and serves as a surrogate for the investment opportunity set (IOS). Past research indicates that the IOS may also be associated with management turnover because firms with a greater IOS 
demand high-quality managers (Smith and Watts, 1992).

Pr $e_{-}$pro is a dummy variable to show whether a previous top executive (chairman or CEO)

had a political background or experience. An owner may select an executive with special knowledge or experience that the previous executive who failed in running the business did not possess.

To examine the post-appointment change in firm performance, corporate governance, and government assistance, we provide mean values surrounding the event year (year 0 , in which the replacement of an executive occurred) and run a t-test of the difference between the year after replacement and appointment (year $+\mathrm{t}$ ) and the event year (year 0).

\section{Data and Sample}

\subsection{Data and sample}

The data on top manager (chairman or CEO) changes in all listed Chinese firms from 2001 to 2005 are obtained from the China Securities Markets and Accounting Research (CSMAR) database. Information on the backgrounds of the chairmen, CEOs, and companies is collected by reading annual reports or summaries of top management resumes published on the finance Web pages http://finance.sina.com.cn/stock/ or http://finance.cn.yahoo.com. The CSMAR database serves as the primary source for the financial data used.

Several firms are excluded from the sample. Non-state firms are excluded because the motivation of private owners in selecting top management, which is not the focus of this study, is different from that of state owners. Also excluded are firms in which the incumbent chairman or CEO left for natural reasons, such as (i) retirement or expiration of an acting position; ii) health; 
iii) a change in ownership, for example, privatization; and iv) resignation. Firms lacking information on their ultimate controlling shareholders or financial issues, and financial institutions (1-digit SIC code: I) are also excluded. ${ }^{8}$ The final sample consists of 696 listed state-owned enterprises in China from 2001 to 2005.

\subsection{Sample Description}

Table 1 reports a description of the background of newly appointed top executives during the period 2001 to 2005. The third column describes the distribution of the political backgrounds of all of the appointed top executives in the sample. The final sample consists of 3,069 firm years, among which 689 firm-year observations involve a change in either the incumbent chairman of the board or CEO and a new appointment. More than half of the newly appointed chairmen or CEOs have a political background, with 53\% having experience in various government entities and $79 \%$ having experience in party positions, including Party Secretary, Central Committee Member or Representative of the People's Congress (some have overlapping experience in the period considered). Looking at the sample of chairmen, the first column of Table 1 shows that 369 firm-year observations involve the appointment of a new chairmen, $65 \%$ of whom have a political background. Looking at the sample of CEOs, the second column of Table 1 shows that 493 firm-year observations involve the appointment of new CEOs, 38\% of whom have a political background. Overall, it appears that state owners value a political background when selecting a new top executive, but more so for chairmen than for CEOs. ${ }^{9}$

\section{[Table 1]}

Table 2 describes the distribution of the appointment of political top executives and

\footnotetext{
8 The SASAC's mandate does not cover financial organizations. The supervision of financial institutions is the responsibility of the Central Banking Supervisory Committee (CBRC). In financial institutions, ownership and regulatory functions are more clearly separated.

${ }_{9}$ Anecdotal evidence indicates that chairmen in Asia have the ultimate decision rights over corporate operations.
} 
non-political top executives by Chinese SEC one-digit industry. The table shows that the turnover of top executives is more frequent in industries such as heavy construction (E), wholesale trade and retail $(\mathrm{H})$, real estate $(\mathrm{J})$, social service and infrastructure $(\mathrm{K})$, and media and communication (L). More specifically, industries such as agricultural production (A), heavy construction (E), real estate (J), and media and communication (L) have a higher frequency of appointing political executives compared with the overall mean frequency of 0.12 , and that the performance of firms in these industries is poorer than the overall mean. For example, in the agricultural production industry, 18\% of firms appoint new political executives (larger than the overall mean of .12). In contrast, industries such as mining (B), manufacturing and petrochemicals (C), transportation (F), and others (M) have a lower frequency of appointing political executives compared with the overall mean of 0.12 . It is noteworthy that regulated industries, including power, oil, and water (D), real estate (J), infrastructure and social services (K), and media and communications (L), have a higher frequency of appointing political executives. These results imply that state owners are likely to have reasons other than (poor) performance to appoint political executives in these industries.

[Table 2]

\section{Empirical Results}

\subsection{Politically Connected Top Management and Past Firm Performance}

Table 3 provides the descriptive statistics and univariate analysis results for the appointment of political top executives in distressed and non-distressed firms. Panel A partitions the sample into low ROA and high ROA groups based on whether or not the ROA of a firm beat the median ROA for an industry-year. Whereas $14 \%$ of the low-ROA firms selected and appointed a new 
executive with a political background, only $11 \%$ of the high-ROA firms selected a political executive. The Wald Chi-square test of difference is significant (the t-value is 3.360). This finding indicates that poorer performing firms select significantly more political executives than firms with good performance. Panel B partitions the sample into loss and no-loss groups according to negative net income. The loss firms changed their chairman or CEO more frequently than the non-loss firms, which is consistent with the literature and is evidence of a higher management turnover rate following poor performance as a disciplinary mechanism (Warner et al., 1988; Coughlan and Schmidt, 1985; Weisbach, 1988). Whereas 19\% of the loss firms selected and appointed a new top executive with a political background, only $12 \%$ of the non-loss firms selected a politically connected top executive. This finding indicates that loss-making firms are more inclined to select politically connected top executives than non-loss firms. Panel C partitions the sample into two groups based on whether or not a firm violated regulations or laws. Twenty per cent of the violating firms selected and appointed a new executive with a political background compared with only $12 \%$ of the non-violating firms. Panel D partitions the sample into high debt-to-assets ratio (high DA) and low debt-to-assets ratio (low DA) groups, and shows that high-DA firms selected significantly more political executives than do low-DA firms. The univariate analysis supports the helping-hand hypothesis on incentive alignment or managerial talent in Section 3.1.

\section{[Table 3]}

Table 4 presents the logistic regression for the replacement and appointment of top executives associated with past firm performance. The dependent variable is the dummy variable for the appointment of top executives (chairman of the board or CEO). Various variables for firm performance and distress are the main independent variables. The control variables include Firm 
Size $(\log ($ Assets $))$; Ownership Concentration (percentage of shareholding that the ultimate state owner holds), which is a proxy for the control rights of the state owner; Employment ( $\log ($ Employee) ), which controls for the number of employees because SOEs and politicians share the social goal of employment; Region Variety $(\log (G D P))$, which controls for economic and labor market conditions; the industry median market-to-book ratio (Indus_MB) as determined by two-digit SIC code, which is a surrogate for the investment opportunity set (IOS); and a dummy variable ( $\operatorname{Pr} e_{-}$pro) that measures whether the previous top executive (chairman or CEO) had no political background or experience. Year and industry dummies are included in the regressions, but for the sake of brevity the results are not reported in the table.

In Panel A, firm performance or distress is measured by a firm's ROA or a dummy variable for earnings loss. The results in the first and fourth columns show that the overall management turnover in Chinese SOEs increases significantly with past poor firm performance or distress, which is consistent with previous studies (Groves et al., 1995; Chang and Wong, 2004). The second and fifth columns presents the regression results for the appointment of top executives with a political background, which is significantly negatively associated with firm accounting performance (ROA) in the lag period (coefficient is -1.47 and p-value is 0.042 ). The appointment of such executives is also significantly positively associated with the earnings loss dummy in the lag period (coefficient is 0.52 and p-value is 0.046 ). For comparison, the third and sixth columns present the regression results for the appointment of executives with no political background. In 304 firm-year observations, a chairman or CEO was selected who had neither government nor party political experience. In contrast to the results for the appointment of political top executives, the appointment of non-political executives is not significantly associated with past firm performance as measured by ROA, but it is associated with earnings loss as significantly as 
the likelihood of the appointment of political executives. Among the control variables, firm size has a significantly negative effect on the selection of non-political executives, which suggests that state owners are more likely to appoint non-political executives to smaller SOEs. Pr $e_{-}$pro is significantly and positively associated with the appointment of political executives, which suggests that the more likely the appointment of a non-political executive, the less likely that political expertise is valued in the new appointment.

In Panel B, firm performance or distress is measured by a firm's financial risk, as measured by a dummy variable for the top quartile debt-to-assets ratio of the industry-year or a dummy variable for the regulations violation. The results in the first and fourth columns are to be consistent with those in Panel A, in that the overall management turnover in Chinese SOEs increases significantly with firm distress. The second and fifth columns present the regression results for the appointment of top executives with a political background, and show that it is significantly positively associated with a firm's financial risk (the coefficient is 0.36 and the $\mathrm{p}$-value is 0.045 ) and the regulations violation dummy (the coefficient is 0.68 and the p-value is 0.019). In contrast to the results for the appointment of political top executives, the third and sixth columns present the regression results for the appointment of executives with no political background. The appointment of non-political executives is not significantly associated with firm distress in terms of a high degree of financial risk or regulations violation. As Panel A reports, only firm size and $\operatorname{Pr} e_{-}$pro have a significant effect on the selection of top executives with different origins.

\section{[Table 4]}

In summary, the regression results support the helping-hand hypothesis that state owners prefer to appoint top executives with political expertise to firms that are in distress. 


\subsection{Management Appointment and Post-appointment Firm Performance and Corporate}

\section{Governance}

In this section, we investigate the changes that the appointment of politically connected top managers brings to SOEs by examining operating performance, corporate governance, and government assistance before and after the appointment of new top executives. This analysis centers on the questions of economic efficiency and management productivity.

i) Pre- and post-appointment firm performance

To evaluate the firm performance of SOEs that appointed a political executive, we calculate the mean ROA, frequency of reporting an earnings loss, leverage ratio, and frequency of violating regulations for each of the six years surrounding the appointment (event years -2 through +3). A comparison of pre-appointment and post-appointment performance is provided in Table 5. We then calculate the t-test statistics for the differences compared with the base year (year 0). In terms of accounting performance (ROA), Table 5 shows that firms that appointed a political executive demonstrated poorer performance in the event year 0 (mean ROA is 0.16), with significantly poor performance than in year -2. After such appointments, the ROA in year +1 , year +2 , and year +3 increases significantly to above 0.2 . However, following the appointment of non-political executives, the ROA in the following three years shows only a mild increase that is not statistically significantly higher than the base-year performance. Looking at earnings losses related to the appointment of a political executive, the frequency of losses in year 0 is the highest ( 0.153 or 15.3 percent are loss firms) in the six-year period, and is significantly higher than in year -2. Following the appointment of a politically connected top executive, the frequency of losses decreases significantly to below 0.10 , which is even lower than that before 
such appointments. Similarly, the frequency of violating regulations decreases significantly from 0.061 in year 0 to 0.013 in year +1 (significant with a p-value of 0.013 ), 0.037 in year +2 (not significant), and 0.036 in year +3 (not significant). In contrast, after the appointment of a non-political executive, the frequency of violating regulations increases significantly and continuously. The results for leverage ratio (DA) are relatively weak. Panel C shows that the leverage ratio is highest in year 0 of the appointment of a political executive, and then decreases somewhat. However, after the appointment of a non-political executive, the leverage ratio increases significantly in year +1 and in the two subsequent years. After the appointment of a political executive, although the leverage ratio decreases, the overall leverage is higher than after the appointment of a non-political executive. ${ }^{10}$ In general, the findings indicate that firm distress is alleviated significantly following the appointment of a politically connected top executive. Such improved performance, however, is not detected following the appointment of a non-politically connected executive.

\section{[Table 5]}

ii) Pre- and post-appointment corporate governance

To find out whether the improved performance after the appointment of politically connected top managers is associated with the disciplinary role and managerial talent of political executives or to government bailouts, we first examine corporate governance after a change in top executive. Table 6 uses various corporate governance measures and reports the governance quality surrounding the appointment of top executives, including discretionary accruals (Kothari et al., 2005), the percentage of independent directors on the board, the frequency of the chairman

\footnotetext{
10 This result is consistent with the argument of Faccio (2007) that because of their political connections, top managers have better access to banking loans and thus politically connected firms have a higher leverage.
} 
and CEO positions being held by the same person, and the frequency of board meetings surrounding an appointment. ${ }^{11}$ A large body of accounting literature demonstrates that discretionary accruals, which are a proxy for earnings management, are negatively associated with corporate governance quality (Xie et al., 2003). The findings in Table 6 (a) show that discretionary accruals decrease significantly by 0.005 (with a p-value of 0.101 ) in the first year following the appointment of a political executive, which means that managerial opportunistic behavior has been mitigated or governance quality has improved following the appointment. In contrast, following the appointment of a non-political executive, discretionary accruals decrease in the first year after the appointment, although not significantly. In the second year after the appointment, however, accruals increase, which indicates more managerial opportunistic behavior after the appointment of a non-political executive. In Panel B of Table 6, the change in the percentage of independent directors is obvious and significant. Irrespective of whether the appointment involves a political or a non-political top manager, the percentage of independent directors on the board increases significantly. Although the appointment of a political executive results in a smaller (not significant) increase in the number of independent directors, the percentage increases significantly more than that pre-appointment, from $27 \%$ in the event year to around $31 \%$ in year +1 , year +2 , and year +3 . This implies that political top executives at least work as well as non-political executives in improving governance quality. Panel C shows that after a political executive is appointed, the frequency of the joint holding of the chairman and CEO positions decreases over time. Although the decrease is not significant, it indicates an improvement compared with the significantly increasing frequency of the joint holding of the

\footnotetext{
11 We calculate discretionary accruals using the model in Kothari et al. (2005), that is $T_{i t} / \operatorname{ASSETS}_{i t-1}=\delta_{0}+\delta_{1}\left(1 / \operatorname{ASSETS}_{i t-1}\right)+\delta_{2}\left(\Delta S A L E S_{i t}-\Delta A R_{i t} / \operatorname{ASSETS}_{i t-1}\right)+\delta_{3} \Delta P P E_{i t} / \operatorname{ASSETS}_{i t-1}+\delta_{4} R A_{i t}+v_{i t} ;$ where the percentage of independent directors on the board is computed as (no. of independent directors / total no. of board directors); the frequency of the chairman and CEO positions being held by the same person is computed as a positive value for a dummy variable for a jointly held chairman and CEO position; and the frequency of board meetings is computed as the number of board meetings held during the year.
} 
chairman and CEO positions after the appointment of a non-political executive. In particular, in year +2 , the frequency of the joint holding of the positions following the appointment of a political executive is significantly less (5.9\%) than that following the appointment of a non-political executive (not reported in the table). Further, Panel D reports that after a political executive is appointed, the frequency of board meetings during the year increases continuously and significantly over time. However, the frequency does not change significantly after the appointment of a non-political executive. This implies that political executives may make more administrative effort than non-political executives to organize management activities.

[Table 6]

iii) Pre- and post-appointment preferential access to resources

To provide more evidence on the disciplinary or monitoring role of political executives in corporate governance, variables representing government bailouts that may accompany politically connected top executives are examined surrounding executive appointments, because some scholars argue that firm performance is improved by the preferential resources brought by political connections, such as preferential access to the credit market, tax discounts, and so forth, rather than by managerial effort. Table 7 shows that following the appointment of political top executives, fiscal subsidies increase but not significantly and are not more than those in the event years of political executives taking position; the tax rate decreases but not significantly; the interest rate does not decrease continuously and significantly; and long-term loans decrease but not significantly. In summary, there is no evidence that political top executives afford firms preferential access to fiscal subsidies, a lower cost of capital, or access to long-term loans, although they are associated with a relatively lower tax rate than non-political executives. These 
results exclude the explanations of preferential access to subsidies or government assistance for the improvement of firm performance surrounding the appointment of a political top executive.

[Table 7]

\subsection{Robustness Tests}

\subsubsection{Multinomial Logistic Analysis}

As a sensitivity test, a multinomial logit model is estimated to show the relative likelihood of the appointment of political top executives. The results show that in response to earnings losses and financial risk, the likelihood of the appointment of a political top executive relative to a non-political top executive is positive and significantly different from $0(+0.43$ with a p-value of 0.072 and +1.42 with a p-value of 0.003 , respectively). This means that the likelihood of the appointment of a political top executive is greater than that of the appointment of a non-political top executive. In response to poor ROA and regulations violation, the likelihood of the appointment of a political top executive relative to a non-political top executive is insignificant. This means that the likelihood of the appointment of a political top executive is not different from that of a non-political top executive given poor ROA and regulations violation. However, the likelihood of the appointment of a political top executive relative to no replacement is positive and significant (-3.81 with a p-value of 0.004 and 0.79 with a p-value of 0.009 , respectively).

\subsubsection{Outsider/Insider appointments}

Among the appointment decisions of top executives, researchers have singled out inside/outside origin as being critical (Helmich, 1977; Dalton and Kesner, 1983, 1985; Boeker 
and Goodstein, 1993; Schwartz and Menon, 1985). They note that firms that are performing poorly are more likely to appoint outsiders than insiders to executive positions, and that outsiders are more often associated with governance changes because they have fewer ties to tradition and precedents. In the robustness checks, we extend the definition of political executives to consider insiders with a political background and outsiders with a political background. Insiders are defined as past or current managers or employees of a firm, and outsiders are defined as all others. We repeat the logistic regression reported in Table 4 using these definitions as the dependent variables. The results (not reported in the table) show that the appointment of outside political executives is significantly associated with poor firm performance and firm distress. However, the likelihood of the appointment of inside political executives is mixed and not significant. These findings support the argument that outsider managers with a political background are perceived to have stronger managerial talents and disciplinary or monitoring effects on corporate governance than insiders.

\section{Conclusions}

This study investigates the appointment by state owners (the government) of politically connected top management to SOEs in China and its impact on subsequent corporate operations and performance. The empirical findings show that Chinese state-owned companies are more likely to replace top executives and appoint a politically connected executive when they encounter a distress such as poor ROA, an earnings loss, a high financial risk, or regulations violation. We also find that newly appointed politically connected top executives subsequently improve firm performance and governance structures and reduce the frequency of illegal action by firms. The evidence is consistent with the helping-hand motive of state owners in the 
appointment of political top managers to SOEs in an effort to improve firm performance, rather than the grabbing-hand motive to extract rents from the SOEs.

In addition, we find no evidence that newly appointed politically connected top executives benefit firms through affording them preferential access to resources or government assistance. The results indicate that the benefits of appointments of political top executives are likely to be due to their managerial talents, not the government subsidies they potentially can bring in to bail out the company.

Finally, the findings in this study of a positive relation between the appointment of politically connected top executives and improvement in firm performance and corporate governance structures provide a better understanding of Chinese government interest and control in stated owned companies and a partial explanation as to why China has experienced remarkably rapid economic growth in the last two decades despite the criticism that the Chinese economy lacks a functioning capital market and significant investor protection and is subject to extensive political influence and control. 


\section{Appendix A: Examples of Appointments of Top Executives in SOEs}

In 2006, the local government appointed Mr. Qi Yumin, who was the former vice mayor of Dalian City in Liaoning Province, to be the new chairman of the board and CEO of Huachen Co. (SEC code: 600653), a local SOE that was a leader in the automobile industry, after three years of reported losses.

In 2003, Mrs Xing Wei, who was a vice minister in the central government, joined the Eastern Tecom Co. (SEC code: 600776), a central enterprise, as a top executive to handle the firm's internal distress.

China Aviation Oil Group Corporation (CNAO.SI), a central enterprise listed on the Singapore stock market, appointed a new chairman of the board in 2006, Mr. Lim Jit Poh, who was a billionaire in Singapore and once worked as a senior officer in the Singapore government, after the firm made a US\$ 0.55 billion loss through investment in the future markets.

In 2006, Wu Liang Ye Wine Co. (SEC code: 000858) announced that Mr. Tang Qiao, vice mayor of Yibin City in Sichuan Province, would replace the incumbent president Mr. Wang Guochun as CEO and party secretary. Wu Liang Ye Wine Co. is a backbone SOE affiliated with the local government of Yibin City, and is a leader in the wine industry. At the time of the announcement, its performance had declined because of relation-party transactions made by the incumbent president Mr. Wang Guochun.

On June of 2004, Luzhou Lao Jiao Wine Co. (SEC code: 000568) announced that Mr. Xie Ming, Secretary of the Community of Luzhou City in Sichuan Province, would replace the incumbent president as CEO and party secretary. Luzhou Lao Jiao Wine Co. is an SOE affiliated with the local government of Luzhou City, and is one of the top four wine companies in the wine industry in China. At the time of the announcement, its industry leadership was threatened because of unsuccessful diversification.

In 2004, Capital Travel Co. (SEC code: 600258) announced that Mr. Zhang Rungang, Vice Minister of the National Travel Bureau, had taken the position of vice president. Capital Travel Co., a central enterprise that used to be top of its industry, had experienced declining earnings and had not even been listed in the top 300 in the hotel and travel industry.

In 2004, SASAC of Zhujiang City appointed Mr. Ye Zhixiong, Chief Director of the Municipal Management Bureau of Zhuhai City and who had no business background, to be president of Gree Electronic Co. (SEC code: 000651). At that time, Gree Electronic Co., a local SOE that was a leader in the electronics industry, had been involved in scandals regarding the illegal conduct of executive staff and had encountered some problems with cash flow.

In 2007, SASAC of Haozhou City appointed Mr. Cao Jie, a subordinate executive and a former Vice Director of the Municipal Taxation Bureau of Haozhou City, to be the new president of Anhui Gujin Wine Group Co. (SEC code: 000596). The management change occurred 
because the incumbent, Mr. Wang Xiaojin, was arrested for corruption. His conduct and his relatives' appropriation had harmed corporate governance and threatened the firm's survival.

In 2005, Baiyun Airport Co. (SEC code: 600004) announced that Mr. Xi Weixiong, Director of the Transportation Bureau of Guangzhou City and a member of the Committee of the Guangzhou government, would serve as the new company president. In 2004, Baiyun Airport Co. had incurred huge costs by moving the location of the airport, which was perceived to have had a negative impact on earnings. However, following the management change, the company had achieved a stable growth in earnings by the end of 2005 .

In 2005, Yili Milk Co. (SEC code: 600887) announced that Mr. Pan Gang, the incumbent CEO and party secretary (and who had once been recognized as an Excellent Party Member) had been appointed as the new president. In 2004, five of the top executives of the firm, including the outgoing president, were arrested for violating regulations and corruption. The firm's performance had declined sharply as a result. 


\section{Appendix B: Key characteristics of jurisdictional regions in China (as detailed in the Government Year Books)}

\section{Country/township level}

This level is under the jurisdiction of the municipal level, and consists of around 2,148 counties and 48,697 townships.

2. Municipal level

This level is under the jurisdiction of the municipal level, and consists of around 333 municipalities or cities.

\section{Provincial level}

This level consists of 27 provinces, including Heibei, Shanxi, Inner Mongolia, Liaoning, Jilin, Heilongjiang, Jiangsu, Zhejiang, Anhui, Fujian, Jiangxi, Shandong, Henan, Hubei, Hunan, Guangdong, Guangxi, Hainan, Sichuan, Guizhou, Yunnan, Tibet, Shanxi, Gansu, Qinghai, Ningxia, and Xinjiang, and the four “direct-rule municipalities” of Beijing, Tianjin, Shanghai and Chongqing (Chongqing is a city that was affiliated with Sichuan Province before 1997. Since 1997, it has been a “direct-rule municipality”).

4. Area level

This level consists of six areas, as follows.

North area (five provincial units): Beijing, Tianjing, Heibei, Shanxi, and Inner Mongolia.

North East area (three provincial units): Liaoning, Jilin, and Heilongjiang.

East area (seven provincial units): Shanghai, Jiangsu, Zhejiang, Anhui, Fujian, Jiangxi, and Shandong.

Central South area (six provincial units): Henan, Hubei, Hunan, Guangdong, Guangxi, and 
Hainan.

South West area (five provincial units): Chongqing, Sichuan, Guizhou, Yunnan, and Tibet;

North West area (five provincial units): Shanxi, Gansu, Qinghai, Ningxia, and Xinjiang.

\section{Central level}

The central level is the ultimate level, over which the central government (guided by the Communist Party) holds the ultimate control rights. 


\section{References:}

Adhikari, Ajay, Derashid, Chek and Zhang, Hao, 2006. Public policy, political connections, and effective tax rates: longitudinal evidence from Malaysia. Journal of Accounting and Public Policy 25, 574-595.

Agrawal, Anup, and Knoeber, Charles R., 2001. Do some outside directors play a political role? Journal of Law and Economics 44, 179-198.

Agrawal, Anup, Jaffe, Jeffrey F. and Karpoff, Jonathan M., 1999. Management turnover and governance changes following the revelation of fraud. Journal of Law and Economics XLII (April)L, 309-342.

Aivazian, Varouj A., Ge Ying and Qiu Jiaping, 2005. Corporate governance and manager turnover: an unusual social experiment. Journal of Banking \& Finance 29, 1459-1481.

Blanchard, O., Shleifer, A., 2001. Federalism with and without political centralization: China vs. Russia in transitional economics: how much progress? IMF Staff Papers 48, 171- 179.

Boeker, Warren and Goodstein, Jerry, 1993. Performance and successor choice: the moderating effects of governance and ownership. The Academy of Management Journal 36 (1), 172-186.

Bonnier, K.-A. and Bruner, R.F., 1989. An analysis of stock price reaction to management change in distressed firms. Journal of Accounting and Economics 11, 95-106.

Cannella, Albert A. and Lubatkin, Michael, 1993. Succession as a Sociopolitical Process: Internal Impediments to Outsider Selection. The Academy of Management Journal 36 (4), 763-793.

Claessens, Stin and Fan, Joseph P. H., 2002. Corporate governance in Asia: a survey. International Review of Finance 3 (2), 71-103.

Chang, Eric C. and Wong, Sonia M. L., 2004. Political control and performance in China's listed firms. Journal of Comparative Economics 36, 617-636.

Chang, Eric C. and Wong, Sonia M. L., 2004. Chief Executive Officer Turnovers and the Performance of China's Listed Enterprises. Working paper.

Chang, Eric C. and Wong, Sonia M. L., 2009. Governance with multiple objectives: evidence from top executive turnover in China. Journal of Corporate Finance, 15, 230-244.

Chen, Dong Hua, Fan, Joseph P.H. and Wong, T.J., 2002. Do politicians jeopardize professionalism? Decentralization and the structure of Chinese corporate boards. Working paper.

Dalton, D. R. and Kesner, I. F., 1983, Inside/outside succession and organizational size: the pragmatics of executive replacement. Academy of Management Journal 26, 736-742.

Dalton, D.R. and Kesner, I.F., 1985. Organizational performance as an antecedent of inside/outside chief executive succession: an empirical assessment. Academy of Management Journal 28, 749-762.

Denis, D.J. and Denis, D.K., 1995. Firm performance changes following top management dismissals. Journal of Finance 50, 1029-1057.

Engel, E., Hayes, R. M. and Want, X., 2003. CEO turnover and properties of accounting information. Journal of Accounting and Economics 36, 1-3.

Faccio, Mara, 2006. Politically connected firms. American Economic Review 96, 369-386.

Faccio, Mara, 2007. The characteristics of politically connected firms. Working paper.

Faccio, Mara, Masulis, Ronald W. and McConnell, John J., 2006. Political connections and corporate bailouts. The Journal of Finance LXI (6), 2597-2635. 
Fama, E. F. and Jensen, M. C., 1983. Separation of ownership and control. Journal of Law and Economics 26, 301-325.

Fan, Joseph P. H., Wong, T. J. and Zhang, Tianyu, 2007. Politically connected CEOs, corporate governance, and Post-IPO performance of China's newly partially privatized firms. Journal of Financial Economics 84 (2), 330-357.

Fisman, Raymond, 2001. Estimating the value of political connections. American Economic Review 91, 1095-1102.

Francis, Bill B., Hasan Iftekhar, and Sun Xian, 2009. Political connections and the process of going public: evidence from China. Journal of International Money and Finance 28, 696-719.

Frydman, R., Pistor, K. and Rapaczynski, A., 1996. Exit and voice after mass privatization: the case of Russia. European Economic Review, 40 (3-5), 581-588.

Gilson, Stuart C., 1990. Management turnover and financial distress. Journal of Financial Economics 25, 241-262.

Groves, Theodore, Hong Yongmiao, McMillan, John and Naughton, Barry, 1995. China's evolving managerial labor market. Journal of Political Economy 103 (4), 873-892.

Guest, R., 1962. Managerial succession in complex organizations. American Journal of Sociology 68, 47-56.

Hadlock, C. J. and Lee, S. D., 2002. Chief executive officer careers in regulated environments: evidence from electric and gas utilities. Journal of Law and Economics, XLV, 535-563.

Hellman, Joel and Schankerman, Mark, 2000. Intervention, corruption and capture: the nexus between enterprises and the state. Economics of Transition 8 (3), 545-576.

Hermalin, B. and Weisbach, M., 1988. The determinants of board composi- tion. RAND Journal of Economics 19, 589-606.

Helmich, D. L. and Brown, W., 1972. Successor type and organizational change in the corporate enterprise. Administrative Science Quarterly 17, 371-381.

Holmstrom, B., 1979. Moral hazard and observability. The Bell Journal of Economics 10, 74-91.

Huson, Mark R., Paul H. Malatesta, and Robert Parrino, 2004. Managerial succession and firm performance. Journal of Financial Economics 74, 237-275.

Jones, L. P., 1985. Public enterprise for whom? Perverse distributional consequences of public operational decisions. Economic Development and Cultural Change, 33 (2), 333-348.

Kato, Takao and Long, Cheryl, 2006. CEO Turnover, Firm Performance and Enterprise Reform in China: Evidence from New Micro Data. Journal of Comparative Economics 34 (4), 796-817.

Kothari, S.P., Leone, Andrew J. and Wasley, Charles E. 2005. Performance matched discretionary accrual measures, Journal of Accounting and Economics 39 (1), 163-197.

Kornai, Janos, 1980. Hard and soft budget constraint. Acta Oeconomia 25, 3-4.

Krueger, A. O., 1990. Government failures in development. Journal of Economic Perspectives 4, 9-23.

Li, David, 2000. Insider control vs. government Control: a study of China's state enterprise reform. Working paper.

Li, Hongbin and Lian, Zhou. 2005. Political Turnover and Economic Performance: The Incentive Role of Personnel Control in China. Journal of Public Economics 89, 1743-1762.

Li, Shaomin, Park, Seung Ho and Li, Shuhe, 2003. The great leap forward: the transition from relation-based governance to rule-based governance. Organizational Dynamics 33 (1), 63-78. 
Maskin, Eric, Qian, Yingyi, and Xu, Chenggang, 2000. Incentives, information, and organizational form. Review of Economic Studies 67, 359-378.

Montinola, G., Qian, Y. and B.Weingast, 1995. Federalism, Chinese Style: The Political Basis for Economic Success in China. World Politics, 48, 50-81.

Morck, R., Shleifer, A. and Vishny, R.W., 1988. Management ownership and market valuation: an empirical analysis. Journal of Financial Economics 20, 293-316.

Oi, J., 1992. Fiscal reform and the economic foundations of local state corporatism in China. World Politics, 45, 99-126.

Opper, S. and Brehm, S., 2007. Networks versus performance: political leadership promotion in China. Working paper.

Peng, Mike W. and Luo Yadong, 2000. Managerial ties and firm performance in a transition economy: the nature of a micro-macro link. Academy of Management Journal 43 (3), 486-501.

Pfeffer, J., 1981. Power in organizations. Marshfield, MA: Pitman.

Pfeffer, J. and Salancik, G., 1978. The external control of organizations. New York: Harpor \& Row.

Puffer, S. and Weintrop, J., 1991. Corporate performance and CEO turnover: a comparison of performance indicators. Administrative Science Quarterly 36, 1-19.

Qian, Yingyi, 1996. Enterprise reform in China: agency problems and political control. Economy Transition 4 (2), 427-448.

Qian, Yingyi, 2000. Government control in corporate governance as a transitional institution: lessons from China. Working paper.

Qian, Yingyi and Gerard, Roland, 1996. The soft budget constraint in China. Japan and World Economy 8 (2), 207-223.

Qian, Y. and Weingast, B., 1997. Federalism as a commitment to preserving market incentives. Journal of Economic Perspectives, 11, 83-92.

Qian, Y. and Xu, C., 1993. Why China's economic reforms differ: the m-form hierarchy and entry/expansion of the non-state sector. Economics of Transition, 1, 135-70.

Rajan, Raghuram and Zingales, Luigi, 1998. Which Capitalism? Lessons Form The East Asian Crisis. Journal of Applied Corporate Finance, Morgan Stanley 11 (3), 40-48.

Rajan, Raghuram and Zingales, Luigi, 2003. The Emergence of Strong Property Rights: Speculation from history. NBER Working Papers 9478, National Bureau of Economic Research, Inc.

Schwartz, K. B. and Menon, K., 1985. Executive succession in failing firms. Academy of Management Journal 28, 680-686.

Shirley, M. and Xu, L. C. (2001). The empirical effects of performance contracts. Journal of Law, Economics, and Organization, 17(1), 168-200.

Shirley, Mary, and Walsh, Patrick, 2000. Public versus private ownership. Policy research working paper. The World Bank.

Shleifer, A. and Vishny, R.W., 1986. Large shareholders and corporate control. Journal of Political Economy 94, 461-488.

Shleifer, Andrei and Vishny, Robert W., 1994. Politicians and firms. Quarterly Journal of Economics 109, 737-783.

Shleifer, Andrei and Vishny, Robert W., 1997. A survey of corporate governance. Journal of Finance, 52, 737-783.

Shleifer, Andrei and Vishny, Robert W., 1998. The grabbing hand: government pathologies and 
their cures. Cambridge, MA: Harvard University Press.

Smith, C. and Watts, R., 1992. The investment opportunity set and corporate financing, dividend and compensation policies. Journal of Financial Economics, 32, 263-292.

Sun, Peng and Zhang, Yi, 2006. Is There Penalty for Crime: Corporate Scandal and Management Turnover in China. Working paper.

Warner, J. B., Watts, R. L. and Wruck, K. H., 1988. Stock prices and top management changes. Journal of Financial Economics 20, 461-492.

Weisbach, M.S., 1988. Outside directors and CEO turnover. Journal of Financial Economics 20, 431-460.

Whiting, S., 2001. Power and wealth in rural China: the political economy of institutional change. Cambridge: Cambridge University Press.

Xie, Biao, Davidson, Wallace N III, and DaDalt, Peter J., 2003. Earnings management and corporate governance: the role of the board and the audit committee, Journal of Corporate Finance 9 (3), 295-316. 
Table 1: Descriptive stats for newly selected top executives' backgrounds during 2001 and 2005. The first column describes either Chairman or CEO appointed, at least one of which has political backgrounds; the second column describes Chairman appointed, who has political backgrounds; the third column describes CEO appointed, who has political backgrounds. The number in the row above is the number of observations and the number in the parentheses below is the percentage.

\begin{tabular}{|c|c|c|c|}
\hline Obs. \# & $\begin{array}{l}\text { Chairman of } \\
\text { the Board }\end{array}$ & CEO & Total \\
\hline All & 3069 & 3069 & 3069 \\
\hline New appointment & $\begin{array}{r}369 \\
(0.12) \\
\end{array}$ & $\begin{array}{r}493 \\
(0.16) \\
\end{array}$ & $\begin{array}{r}689 \\
(0.22) \\
\end{array}$ \\
\hline Obs. \# among newly appointed managers & 241 & 188 & 378 \\
\hline having Politically-connected background & $(0.65)$ & $(0.38)$ & $(0.55)$ \\
\hline Working experience in government & $\begin{array}{r}135 \\
(0.37)\end{array}$ & $\begin{array}{r}89 \\
(0.18)\end{array}$ & $\begin{array}{r}200 \\
(0.29)\end{array}$ \\
\hline Party position such as Party Secretary & $\begin{array}{r}165 \\
(0.45)\end{array}$ & $\begin{array}{r}125 \\
(0.25)\end{array}$ & $\begin{array}{r}272 \\
(0.40)\end{array}$ \\
\hline Central Committee Member & $\begin{array}{r}8 \\
(0.02)\end{array}$ & $\begin{array}{r}6 \\
(0.01)\end{array}$ & $\begin{array}{r}13 \\
(0.02)\end{array}$ \\
\hline Representative of the People's Congress & $\begin{array}{r}11 \\
(0.03) \\
\end{array}$ & $\begin{array}{r}4 \\
(0.01) \\
\end{array}$ & $\begin{array}{r}15 \\
(0.02) \\
\end{array}$ \\
\hline
\end{tabular}


Table 2: The frequency of appointment of political executives and non-political executives by Chinese SEC 1-digit industries. The frequency is calculated as the percentage of total observation numbers.

\begin{tabular}{llrlrr}
\hline $\begin{array}{l}\text { Chinese } \\
\text { SEC }\end{array}$ & Industry Name & $\begin{array}{l}\text { Obs. } \\
\text { 1-digit }\end{array}$ & $\begin{array}{l}\text { Turnover } \\
\text { (Freq.) }\end{array}$ & $\begin{array}{l}\text { Appointment } \\
\text { of political top } \\
\text { executives } \\
\text { (Freq.) }\end{array}$ & $\begin{array}{l}\text { Appointment } \\
\text { non-political } \\
\text { executives } \\
\text { (Freq.) }\end{array}$ \\
\hline A & Agriculture production & 57 & 0.18 & 0.18 & 0 \\
B & Mining & 58 & 0.12 & 0.09 & 0.03 \\
C & Manufacturing \& Petrochemicals & 1788 & 0.22 & 0.11 & 0.11 \\
D & Power, oil \& water & 157 & 0.18 & 0.15 & 0.03 \\
E & Heavy construction & 72 & 0.31 & 0.25 & 0.06 \\
F & Transportation & 139 & 0.19 & 0.11 & 0.08 \\
G & Telecom & 188 & 0.18 & 0.06 & 0.12 \\
H & Wholesale trade \& Retails & 254 & 0.24 & 0.14 & 0.08 \\
J & Real Estate & 88 & 0.34 & 0.26 & 0.05 \\
K & Social service \& Infrastructure & 105 & 0.25 & 0.2 & 0.19 \\
L & Media \& Communication & 16 & 0.44 & 0.25 & 0.1 \\
M & Others & 147 & 0.21 & 0.11 & 0.1 \\
\hline & Total & 3069 & 0.22 & 0.12 & \\
\hline
\end{tabular}


Table 3: The univariate analysis of appointment of political top executives and firm performance / distress. The number above is the number of observations and the number in the parentheses below is the percentage of all sample.

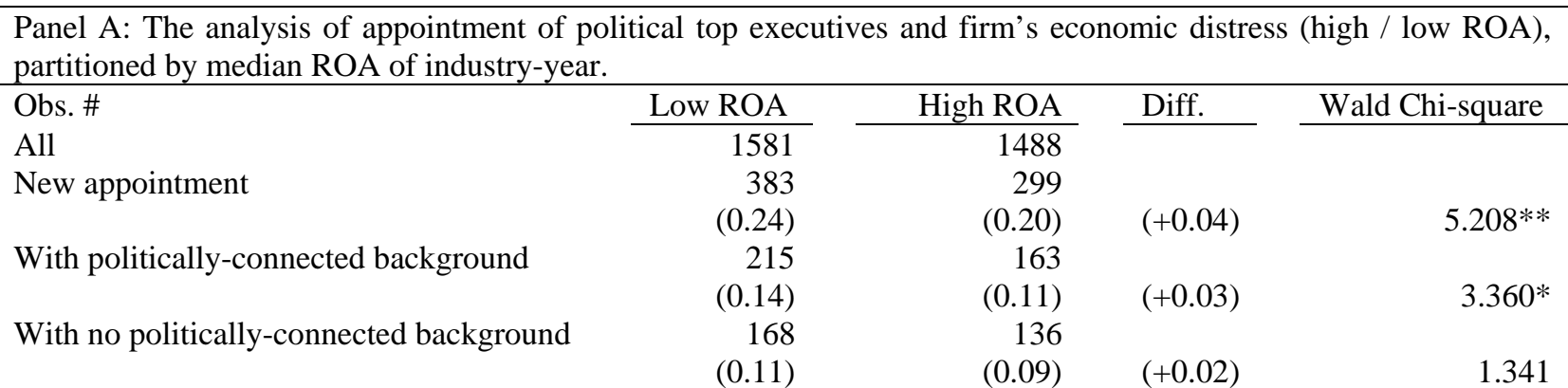

Panel B: The analysis of appointment of political top executives and firm’s economic distress, measured by earnings loss $(\mathrm{NI}<0)$.

\begin{tabular}{|c|c|c|c|c|}
\hline & Loss & No-loss & Diff. & Wald Chi-square \\
\hline All & 301 & 2768 & & \\
\hline \multirow[t]{2}{*}{ New appointment } & 94 & 588 & & \\
\hline & $(0.31)$ & $(0.21)$ & $(+0.10)$ & $15.39 * * *$ \\
\hline \multirow[t]{2}{*}{ With politically-connected background } & 58 & 320 & & \\
\hline & (0.19) & $(0.12)$ & $(+0.07)$ & $14.56^{* * *}$ \\
\hline \multirow[t]{2}{*}{ With no politically-connected background } & 36 & 268 & & \\
\hline & $(0.12)$ & $(0.10)$ & $(+0.02)$ & 2.460 \\
\hline
\end{tabular}

Panel C: The analysis of appointment of political top executives and firm's political distress, measured by regulation violation.

\begin{tabular}{|c|c|c|c|c|}
\hline & $\begin{array}{l}\text { Regulation } \\
\text { violation }\end{array}$ & $\begin{array}{l}\text { No regulation } \\
\text { violation }\end{array}$ & Diff. & Wald Chi-square \\
\hline All & 117 & 2952 & & \\
\hline \multirow[t]{2}{*}{ New appointment } & 39 & 643 & & \\
\hline & (0.33) & $(0.23)$ & $(+0.10)$ & $8.47^{* * *}$ \\
\hline \multirow[t]{2}{*}{ With politically-connected background } & 23 & 355 & & \\
\hline & $(0.20)$ & $(0.12)$ & $(+0.08)$ & $5.91 * * *$ \\
\hline \multirow{2}{*}{ With no politically-connected background } & 16 & 288 & & \\
\hline & $(0.13)$ & $(0.11)$ & $(+0.02)$ & 1.681 \\
\hline \multicolumn{5}{|c|}{$\begin{array}{l}\text { Panel D: The analysis of appointment of political top executives and firm's financial distress (high / low leverage } \\
\text { risk), partitioned by median DA ratio of industry-year. }\end{array}$} \\
\hline \multirow{4}{*}{$\begin{array}{l}\text { All } \\
\text { New appointment }\end{array}$} & $\begin{array}{l}\text { High } \\
\text { Leverage }\end{array}$ & $\begin{array}{r}\text { Low } \\
\text { Leverage }\end{array}$ & Diff. & Wald Chi-square \\
\hline & 1491 & 1578 & & \\
\hline & 341 & 341 & & \\
\hline & $(0.23)$ & $(0.22)$ & $(+0.01)$ & 1.522 \\
\hline \multirow{2}{*}{ With politically-connected background } & 207 & 171 & & \\
\hline & $(0.14)$ & (0.11) & $(+0.03)$ & $6.56^{* * *}$ \\
\hline \multirow{2}{*}{ With no politically-connected background } & 134 & 170 & & \\
\hline & (0.09) & $(0.11)$ & $(-0.02)$ & 2.323 \\
\hline
\end{tabular}

Note: $* * * \mathrm{t}<1 \%, * * \mathrm{t}<5 \%, * \mathrm{t}<10 \%$. 
Table 4: The Logistic regression analysis of replacement and appointment of top executives associated with firm performance. The dependent variable is: i) a dummy for replacement of top executives, i.e. Chairman or CEO; ii) a dummy of appointing political top executives; or iii) a dummy of appointing non-political top executives. The panel A defines the firm performance as accounting performance: firm's return on assets (ROA) or dummy variable for earnings loss. The panel B defines the firm performance as its financial risk, i.e. the top quartile of debt-to-asset ratio of industry year, and political distress, i.e. a dummy variable for firms who violate regulation. The number in the parentheses below is the p-value.

\begin{tabular}{|c|c|c|c|c|c|c|}
\hline \multicolumn{7}{|c|}{ Panel A: the firm performance is measured by the accounting performance: firm's return on assets ROA, or dummy variable for earnings loss. } \\
\hline & \multicolumn{3}{|c|}{ Performance $_{\mathrm{t}-1}=\mathrm{ROA}_{\mathrm{t}-1}$} & \multicolumn{3}{|c|}{ Performance $_{\mathrm{t}-1}=$ Loss $_{\mathrm{t}-1}$} \\
\hline & $\begin{array}{l}\text { Overall } \\
\text { turnover }\end{array}$ & $\begin{array}{l}\text { Appointment of } \\
\text { political executives }\end{array}$ & $\begin{array}{l}\text { Appointment } \\
\text { non-political } \\
\text { executives }\end{array}$ & $\begin{array}{l}\text { Overall } \\
\text { turnover }\end{array}$ & $\begin{array}{l}\text { Appointment of } \\
\text { political executives }\end{array}$ & $\begin{array}{l}\text { Appointment } \\
\text { non-political } \\
\text { executives }\end{array}$ \\
\hline \multirow{2}{*}{ Intercept } & -6.06 & 7.12 & -14.23 & -6.78 & 6.70 & -15.09 \\
\hline & $(0.974)$ & $(0.965)$ & $(0.939)$ & $(0.971)$ & $(0.968)$ & (0.935) \\
\hline \multirow{2}{*}{ Performance $_{t-1}$} & -1.39 & -1.47 & -0.19 & 0.76 & 0.52 & 0.53 \\
\hline & $\left(0.074^{*}\right)$ & $\left(0.042^{* *}\right)$ & $(0.775)$ & $(<.001 * * *)$ & $\left(0.046^{* *}\right)$ & $(0.025 * *)$ \\
\hline \multirow[t]{2}{*}{ Size $_{t-1}$} & -0.15 & 0.04 & -0.24 & -0.12 & 0.05 & -0.20 \\
\hline & $(0.110)$ & $(0.727)$ & $\left(0.026^{* *}\right)$ & $(0.200)$ & $(0.619)$ & $\left(0.06^{*}\right)$ \\
\hline \multirow[t]{2}{*}{ Indusmb $_{\mathrm{t}-1}$} & -0.16 & -0.17 & -0.09 & -0.16 & -0.19 & -0.08 \\
\hline & $(0.421)$ & $(0.477)$ & $(0.677)$ & $(0.418)$ & $(0.433)$ & $(0.721)$ \\
\hline \multirow[t]{2}{*}{ Employee $_{\mathrm{t}-1}$} & -0.07 & -0.09 & -0.02 & -0.07 & -0.09 & -0.02 \\
\hline & $(0.274)$ & $(0.238)$ & $(0.837)$ & $(0.236)$ & $(0.219)$ & $(0.738)$ \\
\hline \multirow[t]{2}{*}{$\mathrm{GDP}_{\mathrm{t}-1}$} & -0.02 & 0.02 & -0.05 & -0.02 & 0.03 & -0.05 \\
\hline & $(0.824)$ & $(0.880)$ & $(0.612)$ & $(0.844)$ & $(0.786)$ & $(0.635)$ \\
\hline \multirow[t]{2}{*}{ Pre_pro } & 14.84 & 3.49 & 2.02 & 14.87 & 3.48 & 2.02 \\
\hline & $(0.278)$ & $(<.001 * * *)$ & $(<.001 * * *)$ & $(0.275)$ & $\left(<.001^{* * *}\right)$ & $(<.001 * * *)$ \\
\hline Industry_Dummy & Yes & Yes & Yes & Yes & Yes & Yes \\
\hline Year_Dummy & Yes & Yes & Yes & Yes & Yes & Yes \\
\hline Obs. \# & 3069 & 3069 & 3069 & 3069 & 3069 & 3069 \\
\hline Psuedo R-square & 0.30 & 0.19 & 0.06 & 0.31 & 0.19 & 0.06 \\
\hline
\end{tabular}


(Conti.)

\begin{tabular}{|c|c|c|c|c|c|c|}
\hline \multicolumn{6}{|c|}{ Panel B: the firm performance is measured by the finacial risk - firm's debt-to-asset ratio, or poliltical distress - dummy variable for violating regulations. } & $\begin{array}{l}\text { olating regulations. } \\
\text { ation violation }\end{array}$ \\
\hline & $\begin{array}{l}\text { Overall } \\
\text { turnover }\end{array}$ & $\begin{array}{l}\text { Appointment of } \\
\text { political executives }\end{array}$ & $\begin{array}{l}\text { Appointment } \\
\text { non-political } \\
\text { executives }\end{array}$ & $\begin{array}{l}\text { Overall } \\
\text { turnover }\end{array}$ & $\begin{array}{l}\text { Appointment of } \\
\text { political executives }\end{array}$ & $\begin{array}{l}\text { Appointment } \\
\text { non-political } \\
\text { executives }\end{array}$ \\
\hline Intercept & $\begin{array}{r}-5.19 \\
(0.978)\end{array}$ & $\begin{array}{r}8.24 \\
(0.960)\end{array}$ & $\begin{array}{r}-14.35 \\
(0.939)\end{array}$ & $\begin{array}{r}-0.55 \\
(0787)\end{array}$ & $\begin{array}{r}-2.02 \\
(0344)\end{array}$ & $\begin{array}{r}-11.38 \\
(0.958)\end{array}$ \\
\hline Performance $_{\mathrm{t}-1}$ & 0.20 & 0.36 & -0.10 & 0.70 & 0.68 & 0.26 \\
\hline & (0.194) & $\left(0.045^{* *}\right)$ & (0.582) & $\left(0.004^{* * *}\right)$ & $(0.019 * *)$ & $(0.381)$ \\
\hline Size $_{t-1}$ & -0.19 & -0.01 & -0.24 & -0.16 & -0.03 & -0.20 \\
\hline & $\left(0.046^{* *}\right)$ & (0.953) & $\left(0.029^{* *}\right)$ & $\left(0.035^{* *}\right)$ & $(0.753)$ & $(0.026 * *)$ \\
\hline Indusmb $_{\mathrm{t}-1}$ & -0.20 & -0.21 & -0.09 & 0.07 & -0.16 & 0.22 \\
\hline & $(0.320)$ & $(0.363)$ & $(0.675)$ & $(0.694)$ & $(0.438)$ & $(0.251)$ \\
\hline Employee $_{t-1}$ & -0.06 & -0.08 & -0.01 & -0.05 & 0.02 & -0.08 \\
\hline & $(0.321)$ & $(0.251)$ & $(0.850)$ & $(0.344)$ & $(0.800)$ & $(0.208)$ \\
\hline $\mathrm{GDP}_{\mathrm{t}-1}$ & -0.02 & 0.02 & -0.05 & 0.03 & 0.05 & -0.01 \\
\hline & $(0.851)$ & $(0.866)$ & $(0.634)$ & $(0.739)$ & $(0.604)$ & $(0.883)$ \\
\hline Pre_pro & 14.83 & 3.50 & 2.02 & 19.38 & 3.37 & 2.05 \\
\hline & $(0.278)$ & $(<.001 * * *)$ & $(<.001 * * *)$ & $(0.951)$ & $\left(<.001^{* * *}\right)$ & $\left(<.001^{* * *}\right)$ \\
\hline Industry_Dummy & Yes & Yes & Yes & Yes & Yes & Yes \\
\hline Year_Dummy & Yes & Yes & Yes & Yes & Yes & Yes \\
\hline Obs. \# & 3069 & 3069 & 3069 & 3069 & 3069 & 3069 \\
\hline Psuedo R-square & 0.30 & 0.19 & 0.06 & 0.31 & 0.19 & 0.07 \\
\hline
\end{tabular}


Table 5: Pre- and post-appointment firm performance of four subsamples: firms changing the executives, firms appointing new political executives, firms appointing new non-political executives and firms having no change of top executives. Mean value are provided around event year (year -2 through year +3 ). Panel A reports performance measured by mean ROA; Panel B reports performance measured by mean frequency of earnings loss; Panel $\mathrm{C}$ reports performance measured by mean Leverage ratio (DA); Panel D reports performance measured by mean frequency of regulation violation. The number in the parentheses below is the p-value of difference between performance in year $t$ and performance in year 0 (the year of change and appointment).

\begin{tabular}{|c|c|c|c|c|c|c|}
\hline \multicolumn{7}{|l|}{ Panel A: mean ROA } \\
\hline \multirow{3}{*}{ Overall turnover } & Year -2 & Year -1 & Year 0 & Year +1 & Year +2 & Year +3 \\
\hline & 0.020 & 0.019 & 0.017 & 0.019 & 0.019 & 0.021 \\
\hline & $\left(0.074^{*}\right)$ & $(0.216)$ & & $(0.245)$ & $(0.286)$ & $(0.312)$ \\
\hline \multirow{2}{*}{ Appointment of political executives } & 0.024 & 0.024 & 0.016 & 0.025 & 0.020 & 0.023 \\
\hline & $(0.044 * *)$ & $\left(0.054^{*}\right)$ & & $\left(0.037^{* *}\right)$ & (0.368) & $(0.104 *)$ \\
\hline \multirow[t]{2}{*}{ Appointment of non-political executives } & 0.022 & 0.021 & 0.018 & 0.019 & 0.019 & 0.021 \\
\hline & $(0.352)$ & $(0.543)$ & & $(0.746)$ & $(0.797)$ & $(0.513)$ \\
\hline \multirow[t]{2}{*}{ No change of top executives } & 0.021 & 0.025 & 0.024 & 0.021 & 0.021 & 0.020 \\
\hline & $(0.145)$ & $(0.206)$ & & $(0.258)$ & $(0.249)$ & $(0.237)$ \\
\hline \multicolumn{7}{|l|}{ Panel B: mean frequency of earnings loss } \\
\hline \multirow[t]{2}{*}{ Overall turnover } & 0.114 & 0.129 & 0.140 & 0.098 & 0.112 & 0.098 \\
\hline & $\left(0.037^{* *}\right)$ & $(0.123)$ & & $(0.115)$ & $(0.204)$ & $(0.165)$ \\
\hline \multirow[t]{2}{*}{ Appointment of political executives } & 0.102 & 0.118 & 0.153 & 0.068 & 0.102 & 0.093 \\
\hline & $(0.056 *)$ & $(0.209)$ & & $\left(0.001^{* * *}\right)$ & $(0.056 *)$ & $\left(0.022^{* *}\right)$ \\
\hline \multirow[t]{2}{*}{ Appointment of non-political executives } & 0.109 & 0.108 & 0.118 & 0.097 & 0.122 & 0.104 \\
\hline & $(0.742)$ & $(0.711)$ & & $(0.441)$ & $(0.902)$ & $(0.608)$ \\
\hline \multirow[t]{2}{*}{ No change of top executives } & 0.099 & 0.095 & 0.087 & 0.104 & 0.100 & 0.104 \\
\hline & $(0.598)$ & $(0.607)$ & & $(0.523)$ & $(0.479)$ & $(0.516)$ \\
\hline \multicolumn{7}{|l|}{ Panel C: mean financial risk (DA ratio) } \\
\hline \multirow{2}{*}{ Overall turnover } & 0.510 & 0.506 & 0.497 & 0.512 & 0.511 & 0.499 \\
\hline & $(0.106)$ & $(0.188)$ & & $(0.139)$ & $(0.129)$ & $(0.512)$ \\
\hline \multirow[t]{2}{*}{ Appointment of political executives } & 0.474 & 0.484 & 0.496 & 0.487 & 0.495 & 0.482 \\
\hline & $(0.147)$ & $(0.423)$ & & $(0.577)$ & $(0.930)$ & $(0.356)$ \\
\hline \multirow[t]{2}{*}{ Appointment of non-political executives } & 0.495 & 0.490 & 0.459 & 0.487 & 0.469 & 0.482 \\
\hline & $\left(0.002^{* * *}\right)$ & $\left(0.046^{* *}\right)$ & & $\left(0.081^{*}\right)$ & $(0.518)$ & $(0.147)$ \\
\hline \multirow{2}{*}{ No change of top executives } & 0.494 & 0.494 & 0.480 & 0.492 & 0.493 & 0.496 \\
\hline & $(0.736)$ & $(0.719)$ & & $(0.678)$ & $(0.747)$ & $(0.691)$ \\
\hline \multicolumn{7}{|l|}{ Panel D: mean frequency of regulation violation } \\
\hline \multirow[t]{2}{*}{ Overall turnover } & 0.041 & 0.039 & 0.060 & 0.047 & 0.051 & 0.049 \\
\hline & $(0.189)$ & $(0.143)$ & & $(0.293)$ & $(0.612)$ & $(0.303)$ \\
\hline \multirow[t]{2}{*}{ Appointment of political executives } & 0.016 & 0.017 & 0.061 & 0.013 & 0.037 & 0.036 \\
\hline & $(0.003 * * *)$ & $(0.003 * * *)$ & & $(0.001 * * *)$ & $(0.162)$ & $(0.155)$ \\
\hline \multirow[t]{2}{*}{ Appointment of non-political executives } & 0.044 & 0.038 & 0.053 & 0.059 & 0.072 & 0.067 \\
\hline & $(0.644)$ & $(0.430)$ & & $(0.763)$ & (0.399) & $(0.507)$ \\
\hline \multirow[t]{2}{*}{ No change of top executives } & 0.037 & 0.038 & 0.034 & 0.036 & 0.035 & 0.035 \\
\hline & $(0.937)$ & $(0.989)$ & & $(0.871)$ & $(0.845)$ & $(0.896)$ \\
\hline
\end{tabular}

Note: ${ }^{* * *} \mathrm{p}<1 \%,{ }^{* *} \mathrm{p}<5 \%,{ }^{*} \mathrm{p}<10 \%$. 
Table 6: Pre- and post-appointment corporate governance of four subsamples: firms changing the executives, firms appointing new political executives, firms appointing new non-political executives and firms having no change of top executives. Mean value are provided around event year (year -2 through year +3 ). Panel $A$ reports the corporate governance measured by the discretionary accruals based on the model (Kothari et al., 2005); Panel B reports the corporate governance measured by percentage of independent directors in the Board; Panel C reports the corporate governance measured by frequency of firm numbers that have duality of Chairman and CEO; Panel D reports the corporate governance measured by the frequency/numbers of Board meeting held during the year. The number in the parentheses below is the p-value of difference between corporate governance in year $t$ and performance in year 0 (the year of change and appointment).

\begin{tabular}{|c|c|c|c|c|c|c|}
\hline \multicolumn{7}{|c|}{ Panel A: mean discretionary accrual based on the model (Kothari et al., 2005) } \\
\hline \multirow{3}{*}{ Overall turnover } & Year -2 & Year -1 & Year 0 & Year +1 & Year +2 & Year +3 \\
\hline & 0.000 & 0.004 & 0.004 & -0.004 & 0.005 & 0.005 \\
\hline & (0.581) & $(0.841)$ & & $(0.132)$ & $(0.814)$ & $(0.866)$ \\
\hline \multirow[t]{2}{*}{ Appointment of political executives } & 0.002 & 0.003 & 0.003 & -0.008 & -0.001 & 0.008 \\
\hline & $(0.942)$ & $(0.771)$ & & $(0.101 *)$ & $(0.578)$ & (0.531) \\
\hline \multirow[t]{2}{*}{ Appointment of non-political executives } & 0.002 & 0.005 & 0.004 & 0.000 & 0.012 & 0.000 \\
\hline & $(0.931)$ & $(0.988)$ & & $(0.570))$ & $(0.303)$ & $(0.614)$ \\
\hline \multirow{2}{*}{ No change of top executives } & 0.001 & 0.003 & 0.002 & 0.000 & -0.001 & 0.002 \\
\hline & $(0.732)$ & $(0.748)$ & & $(0.669)$ & $(0.657)$ & $(0.625)$ \\
\hline \multicolumn{7}{|c|}{ Panel B: mean percentage of independent directors in the Board } \\
\hline \multirow[t]{2}{*}{ Overall turnover } & 0.321 & 0.311 & 0.267 & 0.311 & 0.317 & 0.308 \\
\hline & $\left(<0.01^{* * *}\right)$ & $(<0.01 * * *)$ & & $(<0.01 * * *)$ & $\left(<0.01^{* * *}\right)$ & $\left(<0.01^{* * *}\right)$ \\
\hline \multirow[t]{2}{*}{ Appointment of political executives } & 0.319 & 0.311 & 0.271 & 0.308 & 0.314 & 0.307 \\
\hline & $(<0.01 * * *)$ & $\left(<0.01^{* * *}\right)$ & & $(<0.01 * * *)$ & $\left(<0.01^{* * *}\right)$ & $(<0.01 * * *)$ \\
\hline \multirow[t]{2}{*}{ Appointment of non-political executives } & 0.320 & 0.314 & 0.267 & 0.312 & 0.319 & 0.311 \\
\hline & $(<0.01 * * *)$ & $\left(<0.01^{* * *}\right)$ & & $(<0.01 * * *)$ & $\left(<0.01^{* * *}\right)$ & $\left(<0.01^{* * *}\right)$ \\
\hline \multirow{2}{*}{ No change of top executives } & 0.311 & 0.314 & 0.268 & 0.320 & 0.317 & 0.320 \\
\hline & $(<0.01 * * *)$ & $\left(<0.01^{* * *}\right)$ & & $\left(<0.01^{* * *}\right)$ & $\left(<0.01^{* * *}\right)$ & $\left(<0.01^{* * *}\right)$ \\
\hline \multicolumn{7}{|c|}{ Panel C: mean frequency of dual position of Chairman and CEO } \\
\hline \multirow[t]{2}{*}{ Overall turnover } & 0.082 & 0.071 & 0.056 & 0.055 & 0.071 & 0.086 \\
\hline & (0.112) & (0.159) & & $(0.243)$ & (0.194) & $(0.144)$ \\
\hline \multirow[t]{2}{*}{ Appointment of political executives } & 0.074 & 0.072 & 0.071 & 0.055 & 0.049 & 0.085 \\
\hline & $(0.924)$ & (0.989) & & $(0.413)$ & $(0.242)$ & $(0.540)$ \\
\hline \multirow[t]{2}{*}{ Appointment of non-political executives } & 0.103 & 0.086 & 0.046 & 0.059 & 0.100 & 0.058 \\
\hline & $\left(0.026^{* *}\right)$ & $\left(0.095^{*}\right)$ & & $(0.536)$ & $\left(0.035^{* *}\right)$ & $(0.022 * *)$ \\
\hline \multirow{2}{*}{ No change of top executives } & 0.088 & 0.090 & 0.093 & 0.075 & 0.067 & 0.061 \\
\hline & $(0.212)$ & $(0.315)$ & & $(0.174)$ & $(0.139)$ & $(0.121)$ \\
\hline \multicolumn{7}{|c|}{ Panel D: mean frequency (No.) of Board meeting during the year } \\
\hline \multirow[t]{2}{*}{ Overall turnover } & 7.836 & 7.928 & 7.566 & 7.999 & 8.080 & 8.106 \\
\hline & $(0.155)$ & $(0.307)$ & & $(0.014 * * *)$ & $\left(<.001^{* * *}\right)$ & $(0.007 * * *)$ \\
\hline \multirow[t]{2}{*}{ Appointment of political executives } & 7.336 & 7.877 & 7.426 & 8.114 & 8.215 & 8.003 \\
\hline & $(0.722)$ & (0.532) & & $(0.002 * * *)$ & $\left(<.001^{* * *}\right)$ & $\left(0.016^{* *}\right)$ \\
\hline \multirow[t]{2}{*}{ Appointment of non-political executives } & 8.232 & 8.000 & 7.834 & 7.936 & 7.936 & 7.536 \\
\hline & (0.109) & (0.291) & & (0.711) & (0.711) & $(0.252)$ \\
\hline \multirow[t]{2}{*}{ No change of top executives } & 7.281 & 7.243 & 7.162 & 7.098 & 7.147 & 7.255 \\
\hline & $(0.712)$ & (7.315) & & $(0.774)$ & (0.839) & $(0.721)$ \\
\hline
\end{tabular}

Note: ${ }^{* * *} \mathrm{p}<1 \%,{ }^{* *} \mathrm{p}<5 \%,{ }^{*} \mathrm{p}<10 \%$. 
Table 7: Pre- and post-appointment access to government assistances of four subsamples: firms changing the executives, firms appointing new political executives, firms appointing new non-political executives and firms having no change of top executives. Mean value are provided around event year (year -2 through year +3 ). Panel A calculates ratio of subsidies to total sales; Panel B calculates tax rate, equal to tax expenses / EBIT; Panel C calculates interests rate, equal to interests expenses / long-term loans; Panel D shows the long-term loans scaled by total assets. The number in the parentheses below is the p-value of difference between government assistances in year $t$ and performance in year 0 (the year of change and appointment).

\begin{tabular}{|c|c|c|c|c|c|c|}
\hline \multicolumn{7}{|l|}{ Panel A: mean subsidies scaled by total sales } \\
\hline \multirow{3}{*}{ Overall turnover } & Year -2 & Year -1 & Year 0 & Year +1 & Year +2 & Year +3 \\
\hline & 0.013 & 0.010 & 0.010 & 0.011 & 0.009 & 0.009 \\
\hline & $(0.351)$ & $(0.349)$ & & $(0.326)$ & $(0.301)$ & $(0.311)$ \\
\hline \multirow[t]{2}{*}{ Appointment of political executives } & 0.016 & 0.014 & 0.008 & 0.012 & 0.012 & 0.011 \\
\hline & $(0.240)$ & $(0.465)$ & & $(0.386)$ & $(0.361)$ & $(0.361)$ \\
\hline \multirow[t]{2}{*}{ Appointment of non-political executives } & 0.009 & 0.004 & 0.012 & 0.009 & 0.006 & 0.006 \\
\hline & $(0.303)$ & $(0.243)$ & & $(0.285)$ & $(0.308)$ & $(0.364)$ \\
\hline \multirow[t]{2}{*}{ No change of top executives } & 0.012 & 0.013 & 0.013 & 0.013 & 0.013 & 0.013 \\
\hline & $(0.903)$ & $(0.917)$ & & $(0.926)$ & $(0.918)$ & $(0.922)$ \\
\hline \multicolumn{7}{|l|}{ Panel B: mean tax rate (= tax expense / EBIT) } \\
\hline \multirow[t]{2}{*}{ Overall turnover } & 0.197 & 0.235 & 0.200 & 0.203 & 0.220 & 0.244 \\
\hline & $(0.645)$ & $(0.437)$ & & $(0.889)$ & (0.619) & $(0.091 *)$ \\
\hline \multirow{2}{*}{ Appointment of political executives } & 0.171 & 0.266 & 0.216 & 0.200 & 0.216 & 0.234 \\
\hline & $(0.102 *)$ & $(0.402)$ & & $(0.993)$ & $(0.605)$ & $(0.605)$ \\
\hline \multirow[t]{2}{*}{ Appointment of non-political executives } & 0.232 & 0.192 & 0.180 & 0.207 & 0.224 & 0.258 \\
\hline & $\left(0.051^{* *}\right)$ & $(0.262)$ & & $(0.262)$ & $\left(0.051^{* *}\right)$ & $(0.148)$ \\
\hline \multirow[t]{2}{*}{ No change of top executives } & 0.218 & 0.208 & 0.196 & 0.217 & 0.212 & 0.205 \\
\hline & $(0.514)$ & $(0.428)$ & & $(0.466)$ & $(0.472)$ & $(0.285)$ \\
\hline \multicolumn{7}{|c|}{ Panel C: mean interest rate (= interest expense / average long-term loan) } \\
\hline \multirow[t]{2}{*}{ Overall turnover } & 1.876 & 1.078 & 1.987 & 2.485 & 0.997 & 1.240 \\
\hline & (0.168) & $(0.834)$ & & $(0.644)$ & (0.123) & $(0.196)$ \\
\hline \multirow[t]{2}{*}{ Appointment of political executives } & 1.734 & 1.054 & 1.869 & 2.294 & 0.653 & 1.097 \\
\hline & $(0.155)$ & $(0.190)$ & & $(0.967)$ & (0.918) & (0.918) \\
\hline \multirow[t]{2}{*}{ Appointment of non-political executives } & 2.072 & 1.115 & 2.151 & 2.764 & 1.498 & 1.430 \\
\hline & (0.353) & $(0.534)$ & & $(0.765)$ & $(0.302)$ & $(0.264)$ \\
\hline \multirow[t]{2}{*}{ No change of top executives } & 1.293 & 1.502 & 1.260 & 1.121 & 1.527 & 1.462 \\
\hline & $(0.898)$ & $(0.887)$ & & $(0.964)$ & $(0.896)$ & $(0.921)$ \\
\hline \multicolumn{7}{|c|}{ Panel D: mean long-term loan scaled by total assets } \\
\hline \multirow[t]{2}{*}{ Overall turnover } & 0.048 & 0.054 & 0.053 & 0.051 & 0.053 & 0.052 \\
\hline & $(0.142)$ & $(0.911)$ & & (0.903) & (0.984) & (0.913) \\
\hline \multirow[t]{2}{*}{ Appointment of political executives } & 0.047 & 0.056 & 0.056 & 0.053 & 0.054 & 0.052 \\
\hline & $(0.247)$ & $(0.963)$ & & $(0.929)$ & $(0.922)$ & $(0.922)$ \\
\hline \multirow[t]{2}{*}{ Appointment of non-political executives } & 0.050 & 0.050 & 0.050 & 0.048 & 0.053 & 0.053 \\
\hline & (0.490) & $(0.336)$ & & (0.583) & $(0.460)$ & $(0.478)$ \\
\hline \multirow[t]{2}{*}{ No change of top executives } & 0.059 & 0.058 & 0.057 & 0.058 & 0.058 & 0.058 \\
\hline & $(0.905)$ & $(0.918)$ & & $(0.919)$ & $(0.911)$ & $(0.917)$ \\
\hline
\end{tabular}

Note: ${ }^{* * *} \mathrm{p}<1 \%,{ }^{* *} \mathrm{p}<5 \%,{ }^{*} \mathrm{p}<10 \%$. 